\title{
Evaluation of colorectal cancers in young patients
}

\section{Genç hastalarda kolorektal kanserlerin değerlendirilmesi}

\author{
*Abdullah Kısaoğlu' ${ }^{1}$, Bünyami Özoğul ${ }^{1}$, Sabri Selçuk Atamanalp", Mehmet İlhan Yıldırgan ${ }^{1}$ \\ Gürkan Öztürk ${ }^{1}$, Özgür Hakan Bulut ${ }^{1}$, Ercan Korkut ${ }^{1}$

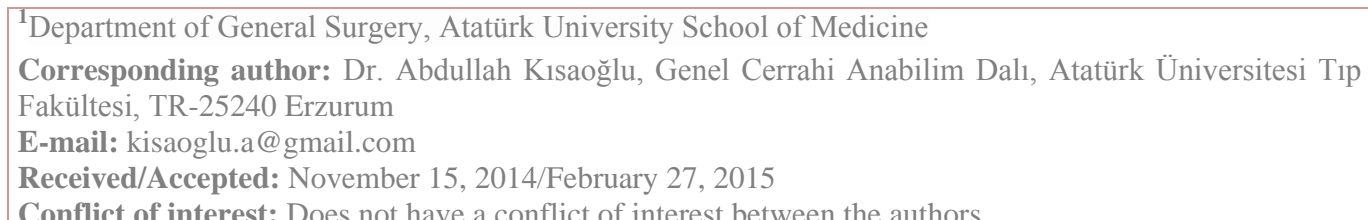

\section{SUMMARY}

Objective: Even though the colorectal cancer is less common in young patients, it has a worse prognosis. The incidence of colorectal cancer in this age group is increasing in recent years. In this study we investigated young patients with colorectal cancer, whose follow-ups and treatments were performed in our clinic, according to the literature.

Method: In our clinic the records of 39 patients under 40 years of age were examined between January 2005 and September 2013 retrospectively. Age and gender of the patients, tumor localizations, the shape of the operation and the tumor pathological features were recorded.

Results: 19 patients (48.7\%) were female, 20 (51.3\%) were male and mean age was 32.6 (19-39) years. 34 patients $(87.2 \%)$ operated electively and 5 patients $(12.8 \%)$ had emergency surgery. The localization of the tumor was mostly in the rectum $(41.0 \%, \mathrm{n}=16)$. For $13(33.3 \%)$ patients, who have the tumor localized in the right column, right hemicolectomy was performed. For patients, who have the tumor localized in the rectum, mostly low anterior resection was performed and totally for 7 patients, a stoma was opened. Pathological investigation revealed mucinous adenocarcinoma in $17(43.6 \%)$ patients.

Conclusion: Rectal cancer is more common in young patients with colorectal cancer and is often diagnosed at an advanced stage. Therefore in this patient group, complaints, which cause suspicion of colorectal cancer, should be examined carefully and advanced inspection methods should be performed.

Keywords: Colorectal cancer, young patient

\section{ÖZET}

Amaç: Genç hastalarda kolorektal kanserler genel popülasyona göre daha az görülmesine rağmen daha kötü prognoza sahiptir. Son yillar içerisinde bu yaş grubunda kolorektal kanserlerin görülme sıklığı artmaktadır. Biz bu çalışmada kliniğimizde takip ve tedavisi yapılan genç kolorektal kanserli hastaların özelliklerini ve sonuçlarımızı literatür ıșığında inceledik.

Yöntem: Kliniğimizde Ocak 2005-Eylül 2013 tarihleri arasında 40 yaș altındaki 39 hastanın kayıtları retrospektif olarak incelendi. Bu hastaların yaşı, cinsiyeti, tümörün yerleşim yeri, operasyonun şekli ve tümörün patolojik özellikleri kaydedildi.

Bulgular: Hastaların 19'u (\%48,7) kadın, 20'si (\%51,3) erkek ve ortalama yaș 32,6 (19-39) idi. Otuzdördü $(\% 87,2)$ elektif, 5'i $(\% 12,8)$ acil opere edilmiști. Tümör en fazla rektumda yerleșik idi (\%41,0; n=16). Tümörün sağ kolonda olduğu $13(\% 33,3)$ hastanın tamamına sağ hemikolektomi, rektumda yerleşen tümörlere de en fazla low anterior rezeksiyon uygulanmış, toplam 7 hastaya stoma açılmıştı. Patolojik inceleme sonucunda $17(\% 43,6)$ hastada müsinöz adenokarsinom görüldü.

Sonuç: Genç kolorektal kanserli hastalarda rektum kanserleri daha sık görülmekte ve genellikle ileri evrede tanı konulmaktadır. Bu nedenle bu hasta grubunda kolorektal kanser şüphesi uyandıran şikayetler titizlikle irdelenmeli ve ileri tetkik yöntemlerine başvurulmalıdır.

Anahtar sözcükler: Genç hasta, kolorektal kanser 


\section{INTRODUCTION}

Colorectal cancers, with one million new patients every year and approximately 500.000 fatalities, are among the very commonly met malignant diseases in the world. The average age for the disease, which is more commonly met in especially 7 th and 8th decades, is $71^{1,2}$. There is an increased incidence of colorectal cancers in the last 40 years in especially young population, in which it is seen at a rate of $2-5 \%$. The clinical features and tumor characteristics of young patients are believed to be different when compared to elderly patients. Not giving importance to their symptoms, delayed manifestation of the symptoms due to the localization of the tumor, and more aggressive clinical progression of the disease during this period lead to the diagnosis of the disease at a later stage especially in young patients. Additionally, the mucinous character and poor differentiation of the tumor in young patients result in bad prognosis ${ }^{4-6}$. In this study, we aimed to evaluate the clinical and pathological characteristics of young patients with colorectal cancer.

\section{MATERIAL AND METHODS}

The charts of 216 patients who underwent operation for colorectal cancer in Atatürk University Medical Faculty, Department of General Surgery between January 2005 and September 2013 were investigated retrospectively. A total of 39 patients who were under 40 years of age were included in the study. Age and gender of these patients together with tumor site, type of operation and pathological characteristics of the tumor were recorded. Patients were evaluated in three groups according to the tumor site as follows: rectum, left colon (sigmoid colon, descending colon, splenic flexure, left half of the transvers colon) and right colon (right half of the transvers colon, hepatic flexure, ascending colon, and cecum).

\section{RESULTS}

Of 216 patients with colorectal cancer treated in our department between January 2005 and September 2013, 39 (18\%) patients were under 40 years of age. 19 of these patients $(48.7 \%)$ were female and 20 $(51.3 \%)$ were male. The mean age of pa- tients was 32.6 (19-39) years. 34 of the patients $(87.2 \%)$ underwent elective operation and $5(12.8 \%)$ underwent emergency operations. When patients were evaluated according to the site of the tumor, 16 $(41.0 \%)$ patients had tumor in the rectum, $13(33.3 \%)$ patients in the right colon and $10(25.7 \%)$ patients in the left colon. Right hemicolectomy was performed in 13 patients with tumors localized in the right colon. Regarding patients having tumors in the left colon, left hemicolectomy was performed in 3, Hartmann procedure in 2 and sigmoid resection in 4 cases. Transvers colectomy was performed in one patient with the tumor localized near the midportion of the transvers colon. Of patients with tumors located in the rectum, 11 underwent low anterior resection and 2 underwent abdominoperineal resection. Since frozen pelvis was identified in 3 patients, resection was not possible and colostomy was performed. Pathological examination revealed mucinous adenocarcinoma in 17 $(43.6 \%)$ cases. Twenty-four $(61.5 \%)$ patients showed moderate differentiation of the tumor, and $21(53.8 \%)$ patients had lymph node metastases. Clinical and pathological findings of the patients are shown in Table 1 . The evaluation made according to the tumor stage revealed Stage I in 3 patients $(7.7 \%)$, Stage II in 8 patients $(20.5 \%)$, Stage III in 13 patients $(33.3 \%)$ and Stage IV in 15 patients (38.5\%). According to the TNM classification, $18(46.2 \%)$ patients were in $\mathrm{T} 4,7$ $(17.9 \%)$ patients were in N1, $10(25.6 \%)$ patients were in $\mathrm{N} 2$, and $15(38.5 \%)$ were in M1. The staging according to the TNM classification of the patients is shown in Table 2.

The average time between the onset of the symptoms of the patients and surgery was 97.6 days. At the postoperative period, wound infection developed in 4 patients and atelectasis in 2 patients. There was no mortality in the early postoperative period. Except the group of 7 patients which consisted of 3 patients with unresectable tumors, 2 patients with Hartmann procedure and 2 patients with abdominoperineal resection, no stoma was performed and no anastomotic leakage was observed. The average hospital stay of patients was 8.1 days. 
Table 1: Clinical and pathological findings of patients.

\begin{tabular}{l|cc}
\hline Age (year) & & $32.6(19-39)$ \\
Gender & Male & $20(51.3 \%)$ \\
& Female & $19(48.7 \%)$ \\
Tumor localization & Rectum & $16(41.0 \%)$ \\
& Right colon & $13(33.3 \%)$ \\
& Left colon & $10(25.7 \%)$ \\
& Low anterior resection & $11(28.2 \%)$ \\
Type of surgery & Right hemicolectomy & $13(33.3 \%)$ \\
& Left hemicolectomy & $3(7.7 \%)$ \\
Pathological diagnosis & Sigmoid resection & $4(10.3 \%)$ \\
& Hartmann procedure & $2(5.1 \%)$ \\
& Abdominoperineal resection & $2(5.1 \%)$ \\
& Transvers colectomy & $1(2.5 \%)$ \\
Differentiation & Unresectable & $3(7.7 \%)$ \\
Metastatic lymph nodes & Adenocarcinoma & $19(48.7 \%)$ \\
& Mucinous adenocarcinoma & $17(43.6 \%)$ \\
& Other & $3(7.7 \%)$ \\
& Moderate & $24(61.5 \%)$ \\
& Poor & $4(10.3 \%)$ \\
\hline & Other & $11(28.2 \%)$ \\
& Present & $21(53.8 \%)$ \\
& No & $18(46.2 \%)$ \\
\hline
\end{tabular}

Table 2: TNM classification of patients.

\begin{tabular}{|c|c|c|c|c|c|}
\hline $\mathbf{T}$ & & $\mathbf{N}$ & $\mathbf{M}$ & Stage & \\
\hline T0 & $0(0 \%)$ & N0 $18(46.2 \%)$ & M0 $24(61.5 \%)$ & I & $3(7.7 \%)$ \\
\hline $\mathrm{T} 1$ & $1(2.5 \%)$ & N1 $7(17.9 \%)$ & M1 $15(38.5 \%)$ & II & $8(20.5 \%)$ \\
\hline $\mathrm{T} 2$ & $4(10.3 \%)$ & $\mathrm{N} 2 \quad 10(25.6 \%)$ & & III & $13(33.3 \%)$ \\
\hline T3 & $16(41.0 \%)$ & NX 4(10.3\%) & & IV & $15(38.5 \%)$ \\
\hline $\mathrm{T} 4$ & $18(46.2 \%)$ & & & & \\
\hline
\end{tabular}

\section{DISCUSSION}

Even though the colorectal cancers are most commonly seen in 7th and 8th decades, there are some studies which have shown that the incidence of the disease has increased in young patients in recent years. In elderly patients, the excision of polyps by screening colonoscopies before carcinoma development is of utmost importance. Non-implementation of this method in young patients, leads to the inability to diagnose the disease in the early period ${ }^{7}$.

Which age group should be called as young age? In this regard, there are authors suggesting that patients under 40 and 30 years of age should be considered as young patients. In a published review article on patients with colorectal cancer, the ratio of young patients to the overall patient group having colorectal cancer was reported as
$0.4-35.6 \%$ (mean 7\%). In this review article, while the majority of the authors have considered the age under 40 as young patient, some authors have accepted the age under 30 as being young ${ }^{8}$. In our study, we considered the age under 40 as young patient group and $18 \%$ of our patients were under the age of 40 . This ratio was consistent with the literature data. In terms of gender of the patients, various kinds of data exist in the literature. In their study, Shemesh-Bar et al. ${ }^{9}$ have reported that colorectal cancers of the young age group were observed in female patients with a rate of $46-65 \%$, in patients having positive family histories with a rate of $46-61 \%$ and in patients having genetic origins with a rate of $1-5 \%$. Berut $\mathrm{M}$ et al. ${ }^{10}$, in their study, determined the male ratio as $60.7 \%$ and Ben-Ishay $\mathrm{O}$ et al. ${ }^{11}$ as $48.7 \%$. In our study, 20 patients $(51.3 \%)$ were male. 
Different tumor sites regarding colorectal cancers have been reported in various studies for young patients. In one study, data of 56 patients under age of 40 were analyzed and the rate of tumor localized in rectum was identified as $76.7 \%$, in rectum and left colon as $84 \%$ and in right colon as $16 \%{ }^{10}$. In their study, Minardi AJ Jr et al. ${ }^{12}$ determined the incidence of right colon cancers as $38 \%$ and cancers of left colon and rectum as $62 \%$. Both studies have demonstrated that mostly, tumors of rectum and left colon are observed in young patients. In our study, the incidence of tumor located in rectum was $41.0 \%$, in rectum and left colon $66.7 \%$ and in right colon $33.3 \%$. Our results were consistent with the literature.

Young patients do not pay attention to symptoms suggestive of colorectal cancers such as abdominal pain, constipation, diarrhea and rectal bleeding and they do not let their complaints be investigated satisfactorily. Similarly, in patients belonging to this age group, doctors relate the presenting complaints to benign diseases such as hemorrhoids and anal fissures and do not resort to further investigative techniques. This situation leads to delays in diagnosis of colorectal cancers in young patients. Studies on this topic have shown that in young patients, the disease usually has already advanced to Stage III when it was diagnosed ${ }^{10,13}$. Berut $\mathrm{M}$ et al. ${ }^{10}$ have found that Stage III cancer rate was $30.3 \%$ and Stage IV cancer rate was $35.7 \%$. In another study, Stage IV colon cancer rate was found as 21.5$38.7 \%$, and Stage I cancer rate as 3.2$15.6 \%$ in young patients ${ }^{11}$. In one study, in which age of 50 was considered as the limit, Stage III rate was determined as 34\% and Stage IV rate as $22 \%$. In our study, Stage I cancer rate was $7.7 \%$, Stage III $33.3 \%$ and Stage IV 38.5\%. Although our rate for Stage III cancer was consistent with the literature, our rate for Stage IV cancer was slightly higher than the data in literature. It was observed that young patients with colorectal cancers were diagnosed in advanced stages in our region. Patients admitted with complaints such as rectal bleeding, changes in bowel habits, chronic abdominal pain and bloat- ing should be investigated meticulously and sigmoidoscopy and/or colonoscopy should be performed with suspicion of colorectal cancer even when they are young.

Thirty four of our patients underwent elective surgery following identification of the lesion site by colonoscopy. Among 5 patients operated on an emergency basis, the tumors were unresectable in 3 patients and sigmoid loop colostomy was performed. The other 2 patients underwent Hartmann procedure. In young patients, failure to remove the tumor and being exposed to permanent colostomy affect the ongoing life of the patient negatively in social and psychological aspects. While unresectability rate was $19.6 \%$ in one study $^{10}$ and $14 \%$ in another ${ }^{2}$, it was determined as $7.7 \%$ in our study. With the onset of the complaints, both patient and physician should give importance to those symptoms and should elucidate the current situation by further investigative techniques. Thus, we can decrease the rate of exposure of new patients to permanent colostomy to a minimum.

Mucinous adenocarcinoma and poor differentiation, revealed in pathological examination, affect prognosis adversely. In conducted studies, these two features were reported to be detected in higher rates in young patients ${ }^{14}$. Berut $\mathrm{M}$ et al ${ }^{10}$ reported the rate of mucinous carcinoma as 55\% and poor differentiation ratio as $9.6 \%$. In the study of Zbuk et al. ${ }^{15}$, these rates were $21 \%$ and $27 \%$ respectively. In our study, while rate of mucinous adenocarcinoma was $43.6 \%$, poor differentiation ratio was $10.3 \%$. Rectum was the site of the lesion in $52.9 \%$ of our cases reported to have mucinous adenocarcinoma.

In conclusion; recently, the number of young cases with colorectal cancer is increasing and the disease is diagnosed in advanced stages due to the delay in diagnosis. In order to avoid this delay, the complaints of the patients should be analyzed both by himself and his physician and diagnostic colonoscopy should be performed at an early stage. In this patient group, rectum tumors and mucinous feature were detected more frequently. 
Additionally, it should be kept in mind that permanent stoma due to unresectability of the tumor may lead to social and psychological problems.

\section{REFERENCES}

1. Jemal A, Siegel R, Ward E, Hao $\mathrm{Y}, \mathrm{Xu} \mathrm{J}$, Murray $\mathrm{T}$, Thun MJ. Cancer statistics. CA Cancer J Clin 2008; 58: 71-96.

2. O'Connell JB, Maggard MA, Liu $\mathrm{JH}$, Etzioni DA, Livingston EH, Ko CY. Do young colon cancer patients has worse outcomes? World J Surg 2004; 28: 558-62.

3. Keswani SG, Boyle MJ, Maxwell JP 4th, Mains L, Wilks SM, Hunt JP, O'Leary JP. Colorectal cancer in patients younger than 40 years of age. Am Surg 2002; 68: 871-6.

4. Umpleby HC, Williamson RC. Carcinoma of the large bowel in the first four decades. Br J Surg 1984; 71: 272-7.

5. Chung YF, Eu KW, Machin D, Ho JM, Nyam DC, Leong AF, Ho YH, Seow-Choen F. Young age is not a poor prognostic marker in colorectal cancer. Br J Surg 1998; 85: 1255-9.

6. Adloff M, Arnaud JP, Schloegel M, Thibaud D, Bergamaschi R. Colorectal cancer in patients under 40 years of age. Dis Colon Rectum 1986; 29: 322-5.

7. O'Connell JB, Maggard MA, Liu $\mathrm{JH}$, Etzioni DA, Livingston EH, Ko CY. Rates of colon and rectal cancers are increasing in young adults. Am Surg 2003; 69: 866-72.

8. O'Connell JB, Maggard MA, Livingston EH, Yo CK. Colorectal cancer in the young. Am J Surg 2004; 187: 343-8.

9. Shemesh-Bar L, Kundel Y, Idelevich E, Sulkes J, Sulkes A, Brenner B. Colorectal cancer in young patients in Israel: A distinct clinicopathological entity? World J Surg 2010; 34: 2701-9.

10. Berut M, Mik M, Kędzia-Berut R, Kujawski R, Trzciński R, Dziki Ł, Dziki A. Colorectal cancer in young and elderly patients. Pol Przegl Chir 2013; 85: 446-51.
11. Ben-Ishay O, Brauner E, Peled Z, Othman A, Person B, Kluger Y. Diagnosis of colon cancer differs in younger versus older patients despite similar complaints. Isr Med Assoc J 2013; 15: 284-7.

12. Minardi AJ Jr, Sittiq KM, Zibari GB, McDonald JC. Colorectal cancer in the young patient. Am Surg 1998; 64: 849-53.

13. Leff DR, Chen A, Roberts D, Grant K, Western C, Windsor AC, Cohen CR. Colorectal Cancer in the Young Patient. Am Surg 2007; 73: 42-7.

14. D'Onofrio GM, Tan EG. Is colorectal carcinoma in the young a more deadly disease? Aust N Z J Surg 1985; 55: 537-40.

15. Zbuk K, Sidebotham EL, Bleyer A, La Quaglia MP: Colorectal cancer in young adults. Semin Oncol 200936: 439-50. 